\title{
TAHAP INKUBASI DESAINER DALAM PROSES KREATIF PEMBUATAN DESAIN BATIK STUDI KASUS DI BALAI BESAR KERAJINAN DAN BATIK
}

Dhe Designer's Incubation Stage in the Creative Process of Designing Batik Study Case in The Center for Handicraft and Batik

\author{
Kuncup Putih Kusumadhata', Timbul Haryono², dan Suwarno Wisetrotomo ${ }^{3}$ \\ ${ }^{1}$ Balai Besar Kerajinan dan Batik, Jl. Kusumanegara No. 7 Yogyakarta, Indonesia \\ 2 Program Studi Pengkajian Seni Pertunjukan dan Seni Rupa, Sekolah Pascasarjana Universitas Gadjah \\ Mada, Jl. Teknika Utara, Pogung Kidul, Sinduadi, Mlati, Sleman. \\ ${ }^{3}$ Program Pascasarjana Institut Seni Indonesia Yogyakarta, J. Suryodiningratan 8, Suryodiningratan, \\ Mantrijeron, Yogyakarta
}

Korespondensi Penulis
Email : kusumadhata@gmail.com

Kata kunci: desain batik, proses kreatif, seni dan kerajinan, tahap inkubasi

Keywords: art and handicraft, batik design, creative process, incubation stage

\section{ABSTRAK}

Teori-teori akademis tentang tahapan dalam proses kreatif memiliki banyak jenis dan alternatif, namun memiliki satu tahap yang cukup konsensual dan hampir selalu mempunyai tempat di dalam teori-teori yang bermacam-macam tadi. Tahap inkubasi dalam proses kreatif seorang desainer memberikan keluaran berupa gagasan yang dibutuhkan untuk mencipta. Penelitian ini bertujuan untuk mengetahui bentuk aktivitas yang berlangsung dalam tahap inkubasi pada proses kreatif seorang desainer batik. Metode yang digunakan adalah metode penelitian kualitatif studi kasus, menggunakan metode pengumpulan data dengan wawancara, serta pengamatan langsung dan partisipatoris. Penelitian ini menemukan dukungan data lapangan terhadap teori tentang tahap inkubasi dalam proses kreatif. Tahap inkubasi yang dialami desainer batik terbagi menjadi dua jenis, jenis pertama adalah inkubasi melalui aktivitas-aktivitas kontemplasi dan relaksasi, dan jenis kedua adalah inkubasi melalui aktivitas-aktivitas distraksi dari fokus permasalahan yang sedang dikerjakan.

\begin{abstract}
Academic theories about stages in the creative process have many type and alternatives, but it have one stage that quite consesual and almost always have a place in those various theories. Incubation stage in designer's creative process give an output in the form of ideas needed for creation. This study aims to determine the form of activities that take place in batik designer's creative process. Method used is case study qualitative research, using data collecting method by interview, and both direct and participatory observation. This study found support for the incubation stage in creative process from field data. Incubation stage experienced by batik designer divided into two types, first is incubation through contemplation and relaxation acivities, and second type is incubation through distraction activities from the focus of the problem being worked on.
\end{abstract}




\section{PENDAHULUAN}

Proses kreatif dari seorang desainer batik bisa bervariasi antara satu subyek dengan subyek lainnya. Hal tersebut tergantung pada konteks dan ruang lingkup dimana batik yang akan diciptakannya itu berada. Untuk mengkajinya, perlu diketahui untuk siapa, apa motivasinya, serta kapan dan di mana desainer menciptakan batik. Semua variabel tersebut bisa diawali dengan menyoroti satu dari beberapa klasifikasi peran dan identitas yang dimiliki batik pada jaman sekarang.

Batik pada masa kini dapat memiliki berbagai identitas, berada dalam berbagai lingkup yang berbeda dan dapat melakoni berbagai peran. Batik dalam masyarakat Indonesia dapat berperan sebagai warisan budaya, komoditas industri, objek seni, kebutuhan sandang primer dan tersier, hingga benda collectible atau klangenan dengan nilai ekonomi yang tinggi. Peran dan identitas batik tersebut di atas bisa dipilah-pilah lagi ke dalam berbagai aspek, tekstual dan kontekstual. Secara tekstual batik mungkin memiliki beberapa aspek seperti dimensi, warna, jenis ragam hias, nama ragam hias, dan lain sebagainya. Namun secara kontekstual batik memiliki aspek-aspek lain yang lebih luas lagi seperti sejarah, falsafah, dan estetika. Aspek estetika yang dimaksud di sini mengacu pada terminologi estetika populer yang memiliki kedekatan makna dengan keindahan.

Aspek estetika dalam batik seringkali dikaji dan diteliti secara akademis dari berbagai sudut pandang. Artikel Kajian Estetika Motif Batik Girilayu Kabupaten Karanganyar contohnya, kajian ini menjabarkan secara deskriptif bagaimana pengaruh lokasi geografis dan aspek historis terhadap estetika motif batik suatu daerah. Dicontohkan pada artikel tersebut bahwa faktor alami seperti melimpahnya tanaman manggis di Girilayu melahirkan ragam hias khas pada batik manggisan dengan gaya khas batik pedalaman (Wardoyo, 2018).

Sudut pandang lain ditawarkan oleh (Ernawati, 2019) dalam artikelnya Kajian Estetika Seni Batik Kontemporer Melalui Karya Kolaborasi Seniman Agus Ismoyo-Nia Fliam. Ernawati mengkaji aspek estetika pada batik kontemporer menggunakan kerangka teoretis fungsi seni yang dipopulerkan oleh Edmund Burke Feldman sejak 1967. Batik sebagai entitas seni memiliki fungsi dekoratif, fungsi sosial, dan fungsi personal sebagai ekspresi estetik berdasarkan pembacaan logika dan rasa.

Judul-judul di atas merupakan kajian akademis dalam bidang batik sebagai objek seni yang menguliti permasalahan estetika pada bagian keluaran dari sebuah proses kreatif, yaitu kain batik itu sendiri. Pada tahapan keluaran ini, batik secara fisik sudah jadi dan siap untuk menerima kritik dan apresiasi. Namun demikian, untuk bisa memahami keseluruhan proses lahirnya batik dari hulu hingga ke hilir, diperlukan lebih banyak lagi kajian seputar proses kreatif desainer batik sebagai pelaku seni yang menjadi titik awal perjalanan batik mulai dari bentuk gagasan hingga menjadi bentuk rupa.

\section{Balai Besar Kerajinan dan Batik}

Balai Besar Kerajinan dan Batik (BBKB) merupakan lembaga pemerintah yang bergerak di bidang litbang, kerjasama, standardisasi, pengujian, sertifikasi, kalibrasi dan pengembangan kompetensi SDM yang menghasilkan litbang berupa teknologi, proses, desain, pemanfaatan bahan baku, serta cara uji kerajinan dan Batik (Wardi, 2017). Tidak seperti instansi kedinasan yang berkutat dengan permasalahan pendanaan, hukum, perijinan, pemasaran, dan lain sebagainya, BBKB lebih memiliki porsi besar pada penelitian dan diseminasi keilmuan tentang kerajinan dan batik Indonesia. Lingkup komoditas keilmuan yang digeluti 
BBKB meliputi batik, dan aneka kerajinan seperti gerabah, anyaman serat alam non tekstil, garmen, kayu, bambu, rotan, dan kerajinan perhiasan non ferro, serta masih banyak lainnya.

Sesuai nama yang disandangnya, BBKB tidak hanya melakukan litbangyasa batik, namun juga kerajinan. Secara umum, batik sebenarnya bagian dari kerajinan. Terminologi kata kerajinan dan batik mengacu pada nama lembaga tersebut. Kata batik disebut secara sendiri dan tidak dilebur dalam istilah kerajinan karena faktor sejarah. Tahun 1922, Pemerintah Hindia Belanda mendirikan lembaga pembina industri tekstil dan batik dengan nama Textile Inrichting En Batik Proefstation yang dalam perkembangannya kini menjadi Balai Besar Kerajinan dan Batik (Eskak, 2020). Dalam nama tersebut dapat diketahui bahwa nama "batik" telah sejak awal digunakan, sebelum ditambahkan kata "kerajinan", karena lembaga tersebut meluaskan tugas dan fungsinya.

Dalam lingkup perancangan desain motif batik, BBKB memiliki dua orang desainer yang bertugas untuk membuat desain motif batik. Disposisi pekerjaan yang diterima kedua desainer cukup beragam. Pekerjaan-pekerjaan tersebut bisa berupa proyek permohonan kerjasama dari pihak eksternal instansi, hingga proyek internal dengan tujuan pengembangan kompetensi atau peningkatan kualitas layanan BBKB. Dalam melakukan pekerjaan mendesain batik, kedua desainer BBKB memiliki satu sistematika kerja tertentu yang berbeda dengan pekerjaan lainnya yang bersifat lebih rutin. Pekerjaan rutin seperti membuat laporan, menyusun rekapitulasi dan sebagainya memerlukan usaha dan waktu yang lebih sedikit dan singkat dibandingkan dengan pekerjaan yang menuntut kreativitas lebih, seperti membuat desain motif batik.
Hal tersebut secara sederhana mendukung gagasan (Lubart, 1994) tentang perbedaan utama antara proses rutin dengan proses kreatif. Pada proses kreatif, durasi, jumlah waktu dan usaha yang dikerahkan untuk setiap tahapannya akan jauh lebih banyak dibandingkan dengan jumlah waktu dan usaha pada proses rutin.

\section{Proses Kreatif Graham Wallas}

Proses kreatif sebagai cabang keilmuan merupakan salah satu dari banyak tema kajian akademis yang melibatkan beberapa disiplin ilmu. Kajian tentang proses kreatif banyak lahir dari irisan keilmuan psikologi dan cabang-cabang seni. Graham Wallas, seorang pakar psikologi sosial dari Inggris pada tahun 1926 mengusulkan gagasan teoritis baru tentang empat tahapan proses kreatif, dalam bukunya The Art of Thought. Menurut Wallas, proses kreatif seseorang akan melalui empat tahapan sebagai berikut; persiapan (preparation), inkubasi (incubation), pencerahan (illumination), dan verifikasi (verification) (Wallas, 1926). Sejak itu penelitian tentang proses kreatif terus dikembangkan, baik penelitian yang mencari dukungan empiris dari bidangbidang spesifik, maupun penelitian yang dilakukan dengan tujuan untuk menyempurnakan teori terdahulu.

Secara sederhana, keempat tahapan proses kreatif tersebut bisa dijabarkan seperti penjabaran berikut; yang pertama tahap persiapan (preparation). Persiapan adalah tahap di mana seorang pelaku seni memberikan input informasi sebanyakbanyaknya pada dirinya tentang permasalahan dalam proyek yang sedang/akan dikerjakannya. Informasi tersebut bersifat komprehensif mulai dari teks hingga konteksnya. Pada tahap ini, semua ide yang berkorelasi dengan permasalahan dalam proyek akan dipelajari dan dimanipulasi secara intelektual (Martindale, 1995). Pengumpulan informasi 
tersebut menjadikan pelaku seni sudah berada dalam keadaan siap dan terbekali oleh semua ilmu, keterampilan, dan pengetahuan yang cukup untuk berkutat dengan permasalahan dalam proyek yang disebutkan tadi.

Tahap persiapan membawa pelaku seni kepada tahapan yang kedua yaitu tahapan inkubasi (incubation). Tahap inkubasi akan dijabarkan lebih lengkap lagi pada subbab berikutnya. Keluaran yang diharapkan dari tahap inkubasi adalah sebuah gagasan/ide yang matang, brilian, dan meyakinkan pelaku seni untuk mengeksekusinya dalam proses produksi.

Ide sebagai keluaran dari pemikiran tadi disebutkan Wallas sebagai tahap pencerahan (illumination). Tahap yang ketiga ini oleh Wallas dibatasi hanya pada momen 'kilatan instan' yang merupakan titik kulminasi dari 'kereta asosiasi' (train of association) yang diakhiri dengan sebuah 'kilatan terakhir' atau sebuah 'klik!' (SadlerSmith, 2015). Terminologi 'kereta asosiasi' dimaknai oleh Sadler-Smith sebagai proses dinamis yang bekerja di antara kondisi sadar (consciousness) dan kondisi tidak sadar (non consciousness). Wallas sendiri menyebutnya dengan 'ide gembira' yang disertai oleh peristiwa-peristiwa psikologi lainnya (Wallas, 1926).

Tahap berikutnya yaitu tahap verifikasi (verification). Tahap ini merupakan tahap yang membedakan teori Wallas dengan teori serupa milik pendahulunya, Hemholtz. Hermann von Hemholtz, fisikawan ternama dari Jerman pada tahun 1891 pernah memaparkan sebuah gagasan tentang tiga tahapan bagaimana sebuah pemikiran baru datang kepadanya. Wallas menangkap esensi dari gagasan Hemholtz dan mengklasifikasikannya ke dalam tiga tahap; persiapan, inkubasi dan pencerahan (Wallas, 1926). Tiga tahap tersebut kemudian disempurnakan dengan menambah satu tahap setelah tahap pencerahan, yaitu tahap verifikasi. Dalam perkembangannya, meskipun gagasan ini tidak terlepas dari usulan modifikasi dan penyempurnaan, teori empat tahapan proses kreatif Graham Wallas masih merupakan teori yang sering dijadikan acuan bagi banyak peneliti kreativitas lain (Sadler-Smith, 2015).

Tahap verifikasi (verification) tersebut merupakan tahap terakhir dari rangkaian proses kreatif. Pada tahap ini validitas ide akan diuji. Tahap verifikasi memiliki kemiripan dengan tahap pertama yaitu persiapan (preparation). Kedua tahap tersebut berlangsung ketika subyek yang melakukan proses kreatif berada dalam keadaan sadar sepenuhnya. Pertimbangan dalam tahap verifikasi mungkin juga melibatkan perhitungan matematis atau pertimbangan logis yang sama dengan yang digunakan pada tahap persiapan (Wallas, 1926).

\section{Tahap Inkubasi dalam Proses Kreatif Modern}

Tahap Inkubasi (incubation) ini berbeda dengan ketiga tahapan lainnya karena inkubasi merupakan satu-satunya tahap yang tidak melibatkan keadaan pikiran yang sadar sepenuhnya. Penelitian ini memberikan fokus pada tahap inkubasi karena tahap ini merupakan tahap yang paling konsensual di antara berbagai macam model teoretis proses kreatif yang pernah ada. Keberadaan tahap ini tidak selalu disebutkan secara tekstual sebagai 'tahap inkubasi'. Beberapa peneliti menggunakan istilah mereka masingmasing untuk menyebut tahapan proses kreatif yang serupa dengan tahap inkubasi. Namun demikian, masih cukup banyak yang menggunakan istilah inkubasi dengan ciriciri dan bentuk yang serupa dengan inkubasi yang dicetuskan oleh Wallas pada tahun 1926.

Beberapa peneliti (paska-Wallas) berikut memiliki tahap inkubasi dalam gagasan teoretis mereka tentang tahapan proses kreatif, diantaranya; Alex Osborn 
pada tahun 1953/1963, Melvin Shaw pada tahun 1989 dan 1994, Mark Runco pada tahun 1997, David Carson pada tahun 1999, Gayle Dow bersama Mark Runco pada tahun 1999, Marion Botella dkk. pada 2011, dan Sadler-Smith pada tahun 2018.

Marion Botella, salah satu dari peneliti yang disebutkan tadi, kemudian mencetuskan sebuah gagasan baru tentang proses kreatif pada tahun 2018. Botella dkk. memperkenalkan model teoretis Enam Tahap Proses Kreatif yang merupakan pengembangan dari model-model teoritis populer, termasuk model teori milik Wallas. Di dalamnya, proses inkubasi bisa ditemukan tertanam pada tahap kedua tahapan proses kreatif, yaitu tahap dokumentasi dan refleksi (documentation and reflection), (Botella et al., 2018). Menurut Botella dkk., sebuah visi atau gagasan pada awalnya hampir selalu bersifat tidak lengkap sehingga memerlukan pertimbangan matang untuk bisa dianggap sebagai satu tahap inkubasi yang baik. Penelitian yang terfokus pada tahap proses kreatif yang konsensual ini bisa bermanfaat bagi penelitian-penelitian modern di bidang proses kreatif dalam berkarya seni pada masa yang akan datang.

Tahap inkubasi sudah dibuktikan memiliki kemampuan untuk membuka semacam pintu gerbang wawasan (insight) di dalam otak (Crawford \& Willhoff, 2013). Kendatipun memegang kunci atas kehadiran " $A-H a$ Moment", solusi, atau inspirasi, tahap inkubasi ini menarik karena kelangsungannya yang tidak disadari dan tidak bisa dikontrol. Tahap ini melibatkan pikiran bawah sadar dan tautan pemikiran (asosiasi) yang bekerja bebas dalam pikiran tanpa disadari.

Kendatipun sama-sama melibatkan pemikiran asosiatif, tahap inkubasi bekerja pada level kesadaran yang berbeda dengan tahap sebelumnya yaitu tahap persiapan. Jika tahap persiapan dilakukan dalam kesadaran penuh, sebaliknya tahap inkubasi dilakukan di bawah atau di tepi kesadaran penuh. Menurut Todd Lubart Lubart (2018), pada momen ketika subyek memutuskan untuk beristirahat dari memikirkan sebuah proyek, sebenarnya pada level pemikiran yang lebih dalam, proses berfikir itu tidak ikut beristirahat.

Wallas mengemukakan dua fakta tentang tahap inkubasi yang disebutkan oleh Sadler-Smith sebagai dua atribut inkubasi (Sadler-Smith, 2015). Fakta yang pertama adalah dalam tahap inkubasi, subyek yang melakukan proses kreatif tidak sedang berada dalam kesadaran penuh atau keinginan untuk memikirkan perihal permasalahan tertentu dalam sebuah proyek. Sementara itu, fakta kedua adalah dalam periode ini akan ada kemungkinan munculnya beberapa mental events yang tidak disengaja. Mental events di sini adalah kejadian dalam pikiran seperti pemikiran, perasaan, atau keinginan (Bunnin \& $\mathrm{Yu}$, 2004). Mental events yang mungkin hadir bisa jadi akan bermuara pada akhir tahap inkubasi sebagai kilatan instan yang memulai tahap selanjutnya, yaitu tahap pencerahan (illumination).

Terminologi baru kemudian diperkenalkan pada tahun 2018 untuk mendeskripsikan tahap inkubasi. Botella et al., (2018) memperkenalkan istilah inkubasi dengan nama break atau jeda. Mereka mengelompokkan dan merangkum tahapan inkubasi yang terdapat pada teori-teori proses kreatif untuk menunjukkan bahwa tahap inkubasi masih relevan dan ditemukan dukungannya pada penelitianpenelitian tentang proses kreatif modern, yang dapat dilihat pada Tabel 1 .

Dalam proses inkubasi, akan muncul banyak kombinasi ide atau asosiasi dalam pikiran. Secara 'otomatis' pikiran bawah sadar subyek akan menolak sebagian besar kombinasi yang 'tidak berguna' sehingga pada akhirnya menemukan satu kombinasi 
ide atau asosiasi yang menjanjikan (Lubart, 2000).

Tabel 1. Tahapan proses kreatif Marion Botella dkk dan kesamaan sifatnya dengan tahapan dari teori proses kreatif yang lain

\begin{tabular}{|c|c|}
\hline $\begin{array}{l}\text { Stages } \\
\text { retaine } \\
d \text { in the } \\
\text { present } \\
\text { study }\end{array}$ & $\begin{array}{l}\text { Correspondence with existing } \\
\text { stages }\end{array}$ \\
\hline $\begin{array}{l}\text { Realizati } \\
\text { on }\end{array}$ & $\begin{array}{l}\text { Synthesis (Osborn, 1953/1963; } \\
\text { Shaw, 1989, 1994) } \\
\text { Production (Treffinger, 1995; } \\
\text { Carson, 1999; Botella et al., 2011) } \\
\text { Realization (Mace and Ward, } \\
\text { 2002) } \\
\text { Implementation (Basadur and } \\
\text { Gelade, 2005; Howard et al., } \\
\text { 2008) } \\
\text { Provisional objects (Botella et al., } \\
\text { 2013) }\end{array}$ \\
\hline $\begin{array}{l}\text { Finaliza- } \\
\text { ion }\end{array}$ & Finition (mace and Ward, 2002) \\
\hline $\begin{array}{l}\text { Judge- } \\
\text { ment }\end{array}$ & $\begin{array}{l}\text { Verification (Wallas, 1926; Busse } \\
\text { and Mansfield, 1980; } \\
\text { Armbruster, 1989; Runco, 1997, } \\
\text { Carson, 1999; Botella et al., 2011) } \\
\text { Evaluation (Osborne, 1953/1963; } \\
\text { Runco and Dow, 1999; Howard } \\
\text { et al. 2008) } \\
\text { Validation (Amabile, 1988; Shaw, } \\
\text { 1989, 1994; Runco, 1997; Botella } \\
\text { et al., 2011; Cropley and Cropley, } \\
\text { 2012) } \\
\text { Assessment (Bruford, 2015) }\end{array}$ \\
\hline $\begin{array}{l}\text { Presen- } \\
\text { tation }\end{array}$ & $\begin{array}{l}\text { Outcome (Amabile, 1988) } \\
\text { Communication (Runci, 1997; } \\
\text { Howard et al., 2008; Cropley and } \\
\text { Cropley, 2012) }\end{array}$ \\
\hline Break & $\begin{array}{l}\text { Incubation (Wallas, 1926; Patrick, } \\
\text { 1937; Osborn, 1953/1963; } \\
\text { Dreistadt, 1969; Shaw, 1989, } \\
\text { 1994; Smith and Blankenship, } \\
\text { 1989, 1991; Smith and Vela, } \\
\text { 1991; Russ, 1993; Runci, 1997; } \\
\text { Carson, 1999; Runco and Dow, } \\
\text { 1999; Botela et al., 2011) }\end{array}$ \\
\hline $\begin{array}{l}\text { With- } \\
\text { drawal }\end{array}$ & $\begin{array}{l}\text { Abandoning (Mace and Ward, } \\
\text { 2002) }\end{array}$ \\
\hline
\end{tabular}

\section{Ciri-ciri Tahap Inkubasi}

Tahap inkubasi bukanlah tahapan yang mudah untuk diidentifikasi, diuji dan dievaluasi. Hal tersebut dikarenakan sebagian besar tahap ini bergantung pada kerja bawah sadar (Botella et al., 2018). Kendatipun tidak mudah, bukan tidak mungkin ciri-ciri dari tahap inkubasi ini diidentifikasi dari beberapa catatan ilmiah dan teori-teori tentang inkubasi.

Yang pertama, tahap inkubasi bisa berlangsung di manapun dan kapanpun. Seorang kreator bisa berinkubasi sembari menyetir, tidur, berolahraga, bahkan ketika sedang mandi. Tahap ini membutuhkan kegigihan, kesabaran, dan percaya diri akan tahap persiapan yang sudah dilakukan. Melalui proses kontemplasi dan relaksasi, sebuah 'kunci jawaban' akan muncul. Salah satu aktivitas favorit di mana biasanya inkubasi berlangsung adalah tidur siang (Lubart, 2018).

Kedua, meski proses kontemplasi dan relaksasi merupakan cara yang efektif, keadaan absennya kesadaran untuk memulai inkubasi tidak selalu berupa kegiatan bersantai. Inkubasi tetap bisa berlangsung ketika subyek mengalihkan perhatiannya dari satu pekerjaan ke pekerjaan lainnya. Cara ini bisa menghemat waktu dan seringkali merupakan cara yang lebih baik (Wallas, 1926).

Ketiga, periode inkubasi akan berakhir ketika satu insight muncul dalam keadaan pikiran sadar menyertai ide baru yang relevan dengan pokok permasalahan yang sedang dikerjakan. Namun demikian, ada kalanya satu atau dua ide yang muncul pada tahap ini masih terasa kabur, abu-abu, atau tidak jelas (Botella et al., 2011).

Kemunculan ciri-ciri tahap inkubasi tidak hanya berada dalam satu jangkauan periode antara tahap persiapan dan pencerahan. Botella \& Lubart (2019) merangkum pendapat beberapa peneliti tentang sifat dinamis proses kreatif ini. Ada kalanya tahap persiapan beririsan dan 
tumpang tindih dengan tahap inkubasi. Ada kalanya pula seseorang yang berada dalam proses kreatif menemukan dirinya melompat-lompat antara tahapan proses kreatif. Pendapat-pendapat dari para peneliti modern ini memperbaharui model teoretis Graham wallas yang memiliki kesan siklikal-statis.

\section{TUJUAN PENELITIAN}

Penelitian tentang tahap inkubasi pada desainer batik BBKB ini bertujuan untuk mengetahui tahapan proses kreatif yang terjadi sekaligus mewacanakan model teoritis proses kreatif dalam bidang seni rupa. Kedekatan seni batik dengan rumpun seni rupa melahirkan keyakinan teoritis bahwa ada kesamaan proses kreatif di antara keduanya. Kendatipun demikian muncul pula keyakinan akan adanya perbedaan tahapan proses kreatif antara cabang seni yang sudah terlebih dahulu diteliti dengan tahapan proses kreatif dalam pembuatan desain batik. Penelitian ini juga bertujuan untuk memberikan stimulus kepada dunia akademik untuk lebih banyak lagi melakukan penelitian proses kreatif yang secara khusus difokuskan pada proses pembuatan desain batik.

\section{METODOLOGI PENELITIAN}

Metode penelitian yang digunakan dalam artikel ini adalah kualitatif studi kasus. Kasus yang diamati adalah periode inkubasi dalam proses kreatif desainer batik di BBKB. Metode penelitian studi kasus akan sesuai dengan medan, waktu, situasi dan kondisi lapangan, serta subyek penelitian. Metode studi kasus bersifat sempit namun mendalam. Hal ini penting ketika penelitian yang dilakukan melibatkan unsur-unsur detail seperti keadaan pikiran (state of mind), suasana hati (mood) dan proses kreatif yang bersifat personal dari subyek penelitian.
Subyek penelitian ini adalah dua orang desainer batik dari BBKB. Penelitian dilakukan dalam rentang waktu bulan Februari hingga Juni 2020. Pengumpulan data dilakukan dengan cara pengamatan langsung, pengamatan non partisipatoris, dan wawancara baik secara langsung maupun tidak langsung, baik secara terstruktur maupun tidak terstruktur. BBKB memiliki dua orang desainer yang bertugas di laboratorium desain. Namun demikian, selain melalui informan utama, data juga dikumpulkan dari pihak kolaborator, kontributor, tenaga ahli yang dalam kesehariannya terlibat langsung dengan kedua desainer BBKB.

Kerangka teori yang diwacanakan adalah beberapa teori yang dikemukakan Wallas, Piirto, dan Botella seperti yang sudah dipaparkan pada pendahuluan dan subbab ciri-ciri tahap inkubasi. Hasil penelitian nantinya akan diwacanakan sesuai dengan landasan teori untuk melihat apakah ada dukungan terhadap teori yang bisa ditemukan dari penarikan kesimpulan.

Pengolahan data dilakukan dengan memindahkan data mentah ke dalam bentuk transkripsi untuk kemudian dilakukan proses koding di dalamnya. Selanjutnya proses triangulasi data dilakukan untuk mengumpulkan data-data yang valid sehingga bisa memudahkan proses analisis dan penarikan kesimpulan. Hasil penelitian disajikan secara naratifdeskriptif.

\section{HASIL DAN PEMBAHASAN}

\section{Proses Kreatif Desainer BBKB}

Kedua desainer BBKB sudah memiliki masa kerja selama kurang lebih sepuluh tahun. Keduanya memiliki latar belakang pendidikan formal dari institusi Perguruan Tinggi dengan fakultas seni rupa dan desain. Dalam menyelesaikan desainnya, masingmasing desainer memiliki tahapan proses kreatif yang serupa namun tidak sama. 
Kedua desainer melakukan berbagai aktivitas dalam satu rentang waktu pengerjaan sebuah proyek (penyelesaian suatu masalah) yang bisa dikelompokkan ke dalam masing-masing tahap dari empat tahapan proses kreatif.

Kedua desainer melakukan riset dan pengumpulan data setiap kali memulai sebuah proyek. Aktivitas tersebut bisa dikelompokkan ke dalam tahap persiapan (preparation). Ketika mendapat ide dan gagasan, kedua desainer menindaklanjuti ide dan gagasan dengan pertimbanganpertimbangan logis dan teknis seperti dimensi ragam hias, korelasi makna dan komposisi, serta beberapa hal lain. Pertimbangan-pertimbangan seperti itu membuat aktivitas tersebut bisa dikelompokkan ke dalam tahap pencerahan (illumination).

Ketika tahap pembuatan desain yang dimulai dari sketsa, hingga pewarnaan, desainer mencari validitas gagasan mereka dengan mencocokkan keluaran yang berupa hasil desain dengan kebutuhan penyelesaian permasalahan dari tahap persiapan. Ketika desain dianggap mampu menjawab kegelisahan desainer pada tahap awal, maka empat tahap proses kreatif berakhir di situ. Sejauh ini kedua desainer menunjukkan beberapa kesamaan dalam tahapan proses kreatif, khususnya pada tahap pertama, ketiga dan keempat. Namun demikian, Ketika dilihat lebih detail pada tahap kedua, yaitu inkubasi, proses kreatif kedua desainer terlihat berbeda tetapi masih mendukung teori yang diwacanakan di atas.

Salah satu hal yang membedakan proses kreatif seorang seniman lepas dan desainer yang bekerja di lingkungan perkantoran adalah batasan berupa waktu dan tempat. Desi Rahayu (2016), dalam skripsinya yang membahas tentang proses kreatif seniman batik Sarwidi dari BayatKlaten memaparkan tentang proses persiapan-inkubasi yang dilakukan Sarwidi.
Sarwidi memulai proses kreatifnya dengan berjalan-jalan, naik sepeda atau sepeda motor, melihat dan mengamati bunga teratai, kemudian ide yang ditunggu muncul di tengah malam dengan bersumber dari aktivitas jalan-jalan dan pengamatan yang dilakukan sebelumnya Hal semacam ini merupakan aktivitasaktivitas yang sulit dilakukan oleh staf perkantoran meskipun berstatus sebagai desainer. Batasan berupa rentang waktu jam kantor dan tempat kerja menuntut para desainer menemukan ritme tersendiri yang sesuai dengan apa yang dibutuhkannya untuk berkreasi.

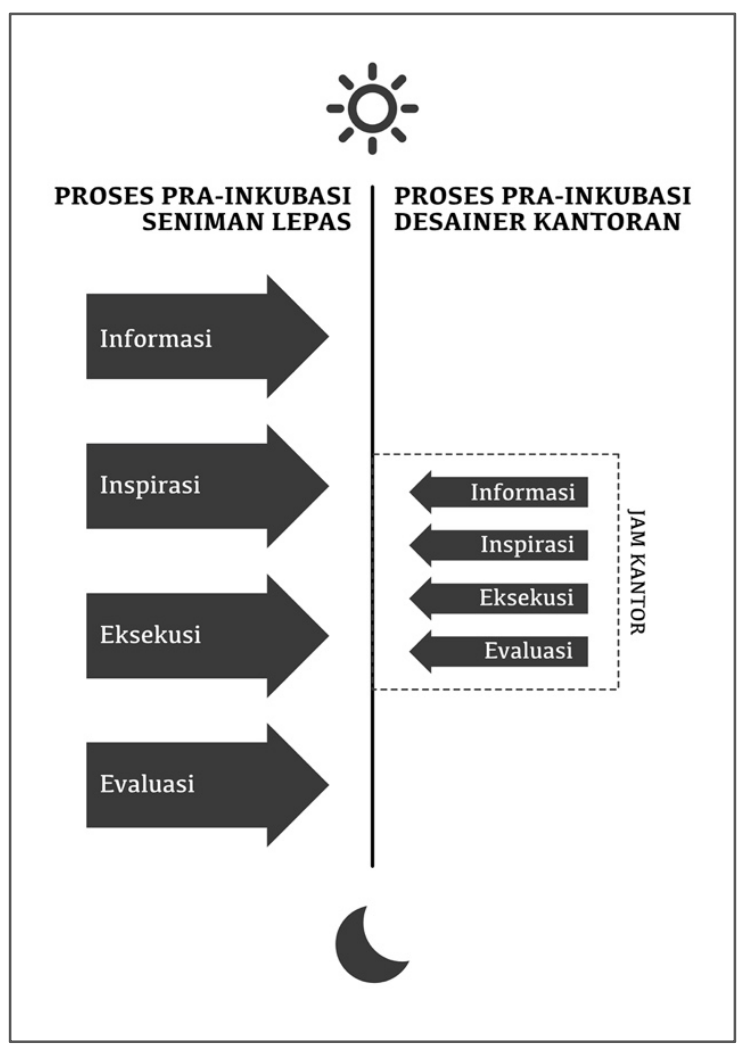

Gambar 1. Bagan Ilustrasi perbandingan pola kerja seniman batik lepas dengan desainer batik kantoran.

Seniman batik yang tidak terafiliasi dengan perusahaan/instansi yang memiliki tempat dan jam kerja khusus bisa mengumpulkan informasi, mendapat inspirasi, melakukan eksekusi produksi hingga evaluasi kapanpun ia mau. Sementara itu desainer batik yang berstatus 
pekerja kantoran akan selalu terikat dengan rentang jam kantor dan ruang kerja yang spesifik, untuk bisa selalu berada dalam pola kerja yang teratur seperti pada Gambar 1. Namun demikian, pada sub-bab berikutnya akan disampaikan tentang kedua desainer BBKB yang beradaptasi dengan kebutuhan informasi serta kemunculan inspirasi di luar jam dan lokasi kantor.

\section{Tempat dan Waktu Periode Inkubasi}

Di tengah-tengah tahap persiapan dan periode pencerahan, ada periode inkubasi yang juga dialami oleh kedua desainer BBKB. Hasil penelitian yang dilakukan menunjukkan bahwa periode inkubasi terjadi pada waktu dan tempat yang sama sekali berbeda bagi kedua desainer. Hal tersebut menjadi pembeda utama bagi keduanya. Pada desainer pertama, periode inkubasi acap kali terjadi di luar jam kantor, sementara desainer kedua sering berada dalam periode inkubasi pada saat jam kantor.

Untuk menjaga kerahasiaan identitas, kedua nama desainer sebagai informan akan disamarkan sebagai Nara dan Wibowo. Nara merupakan pribadi dengan tipe extrovert, karakter pribadi ini periang, suka bercanda, suka bercakap-cakap dan berinteraksi secara sosial dengan rekan kerjanya. Nara memiliki kecenderungan untuk meminta pendapat dari kolaborator atau tenaga ahli dalam satu situasi pengerjaan sebuah proyek. Dalam proses kreatif, karakter extrovert memberi keuntungan bagi desainer ini, khususnya pada tahap pertama yaitu persiapan. Untuk mempersiapkan diri dengan baik pada tahap awal proses kreatif diperlukan banyak input dari segala penjuru seperti 'teks dan konteks', subyek dan obyek, faktor internal dan eksternal dari desainer itu sendiri serta pribadi-pribadi lain yang mengelilinginya.
Nara memiliki kecenderungan untuk memprioritaskan faktor eksternal dalam proses pengumpulan data. Dengan mengumpulkan data dari orang di sekitarnya, data-data seperti pertimbangan pakem, filosofi, teknis produksi dan sebagainya bisa didapatkan dari interaksi sosialnya. Dengan kemampuannya untuk bersosialisasi, serta kemauannya untuk menggali perspektif orang lain, dari orangorang sekitarnya Nara mampu mengumpulkan banyak data yang dibutuhkan untuk berinkubasi. Namun demikian, konsekuensi yang muncul adalah dominasi perspektif eksternal dari lingkungannya menjadi cukup besar. Gagasan tersebut pernah disampaikan Max Freyd (1924) dalam jurnal Psychology Review tentang karakteristik seseorang. Gagasan yang dimaksud adalah bahwa seorang extrovert adalah individu yang di dalamnya terdapat pengurangan proses berfikir dalam hubungannya dengan perilaku sosial yang terlihat jelas, dengan kecenderungan untuk melakukan kontak sosial.

Kendatipun cukup mendominasi, perspektif-perspektif yang dikumpulkan dari kontak sosialnya sesungguhnya memberikan kontribusi banyak pada tahap persiapan, yang mana sangat baik untuk berjalannya tahap selanjutnya yaitu inkubasi. Inkubasi merupakan sebuah lahan subur bagi pemikir kreatif, maka dari itu mengajukan (mematangkan) permasalahan di awal proses kreatif akan memperluas dan memperkaya kerja mental dari pikiran bawah sadar yang mana akan bekerja secara dominan pada tahap inkubasi ini (Sadler-Smith, 2015). Banyaknya input gagasan yang didapat dari orang sekitarnya melengkapi proses berfikir (secara mandiri) yang kurang dominan tadi.

Proses inkubasi yang dialami Nara terjadi di dalam kantor dan di luar kantor, serta dialami pada saat jam kerja dan di luar 
jam kerja. Namun demikian, ujung akhir dari proses tersebut kerap muncul di luar kantor dan di luar jam kerja. Di dalam kantor, selain mendesain batik Nara memiliki berbagai tugas di BBKB seperti; mendesain kerajinan anyaman, mengurus administrasi koperasi dan lain sebagainya. Seperti disebutkan pada sub-bab ciri-ciri inkubasi, keadaan inkubasi bisa dimulai dan bekerja pada saat keadaan apapun termasuk ketika mengerjaan tugas-tugas lain seperti contoh di atas, tetapi tidak akan bekerja seefektif ketika subyek sedang berkontemplasi atau relaksasi. Kehadiran tahap inkubasi diidentifikasi dari indikasiindikasi yang ditampakkan atau dikatakan oleh kedua desainer. Botella et al., (2019) dalam penelitiannya mencontohkan indikasi kehadiran tahap inkubasi yang berupa perkataan seperti "Aku tinggalkan ide-ideku agar mereka saling terhubung dengan sendirinya".

Hasil observasi dan wawancara terhadap Nara mendukung kerangka teoretis tentang kehadiran ciri-ciri tahap inkubasi di atas. Hasil tersebut juga menunjukkan indikasi bahwa tahap inkubasi berakhir saat munculnya insight atau dengan kata lain sudah memasuki tahap yang ketiga yaitu pencerahan. Indikasi tersebut ditarik dari beberapa kata kunci seperti mood, ide, dan pernyataanpernyataan seperti "Oh, iki sing bedo!", atau "Oh kenopo nggak iki yo?" juga beberapa yang dicatat dari pernyataan tentang situasi dimana ide atau gagasan tersebut muncul. Datangnya insight yang digambarkan Nara dengan secara "ujug-ujug" lebih sering dirasakannya saat berada di rumah dan dalam situasi malam hari. Hal tersebut berkorelasi dengan pernyataan Nara bahwa dia merasa kesulitan menemukan ide ketika berada di kantor di mana kondisi ruang kerjanya relatif lebih ramai dan bising.

Salah satu aktivitas yang memicu munculnya insight bagi Nara adalah aktivitas melihat dan memotret langit.
Situasi dan kondisi tempat tinggalnya memungkinkan Nara untuk menikmati pemandangan langit yang indah. Dipaparkannya bahwa kebiasaan tersebut sering mencetuskan gagasan atau ide yang ditunggu-tunggunya, bahkan Nara sering menyarankan metode ini kepada temantemannya yang sedang mencari ide. Aktivitas tersebut merupakan contoh yang sempurna untuk dukungan data lapangan terhadap teori kontemplasi dan relaksasi yang pada akhirnya mengakhiri tahap inkubasi dan mengawali tahap pencerahan.

Desainer kedua, Wibowo memiliki karakteristik yang cukup jauh berbeda dengan Nara. Desainer ini memiliki beberapa ciri karakteristik yang cukup untuk digolongkan ke dalam kelompok pribadi introvert., pribadi ini disebut memiliki proses pemikiran yang dilebihlebihkan dalam hubungannya dengan perilaku sosialnya, juga ada kecenderungan untuk menarik diri dari pergaulan sosial (Freyd, 1924). Pribadi ini cenderung tidak tergantung pada pendapat seseorang untuk menentukan keputusan dalam mendesain. Proses konsultasi desain tetap dijalankan namun tidak pada porsi yang besar, pertimbangan pribadi dalam desain masih lebih dominan.

Wibowo melakukan aktivitas dalam tahap persiapan proses kreatifnya secara mandiri dan cenderung kurang menyukai perjalanan dan survei lapangan. Wibowo menjadikan pola pemikirannya sebagai titik pusat proses kreatifnya, sehingga terkadang poin-poin penting yang secara potensial bisa didapat dari sekitarnya, tidak menjadi pertimbangan utama dalam desainnya. Aktivitas dalam tahap persiapan yang dilakukan Wibowo terjadi dengan cepat karena dua faktor; (1) jam terbang dan kompetensi yang tinggi, (2) masukan dari sumber eksternal selain dirinya sendiri tidak menghalangi proses dalam alur berfikirnya.

Tahap persiapan yang terlalu singkat bukan berarti selalu lebih buruk daripada 
tahap persiapan yang lebih lama, namun memiliki resiko yang lebih tinggi untuk kehilangan detail yang dibutuhkan pada tahap inkubasi. Wibowo yang memiliki keunggulan dengan karakter introvert-nya, bisa menemui lebih banyak keadaan inkubasi secara kontemplatif dan relaks daripada inkubasi secara pengalihan fokus pekerjaan/proyek yang dilakukan. Dengan tidak memiliki "tanggung jawab moral pribadi" untuk bersosialisasi dengan sekitar, proses perenungan bisa berjalan dengan lebih khidmat. Wibowo menyatakan sering mendapat ide yang ditunggu-tunggunya selepas bangun dari tidur, hal ini sesuai dengan pernyataan Lubart (2018) tentang aktivitas tidur yang merupakan aktivitas favorit dalam tahap inkubasi. Momen tersebut pada akhirnya menjadi indikasi utama berakhirnya tahap inkubasi yang diikuti dengan tahap pencerahan.

Wibowo lebih banyak menemui pencerahan di kantor dan pada jam kerja meski juga pernah menemukan pencerahan di luar kantor dan di luar jam kerja. Menurutnya datangnya tahap pencerahan di luar kantor dan di luar jam kerja cukup merepotkan karena mau tidak mau itu membuatnya harus pergi ke kantor untuk mengeksekusi gagasannya pada tahap yang keempat yaitu verifikasi. Kondisi kerja terbaik bagi Wibowo adalah di kantor dan saat jam kerja. Hal tersebut membuatnya lebih sering tidak memforsir proses berfikir seperti pada tahap persiapan dan lebih sering menunggu pencerahan dalam tahap inkubasi.

Aktivitas inkubasi dengan cara berkontemplasi dan relaksasi mungkin bisa terlihat janggal di lingkungan perkantoran, namun proses tersebut terbukti efektif dan bisa memberikan keseimbangan terhadap proses persiapan Wibowo yang relatif lebih singkat dibandingkan dengan Nara. Wibowo menemukan banyak gagasangagasannya di kantor seusai melakukan kegiatan seperti tidur siang, istirahat makan siang, melamun, serta mengambil jeda untuk bermain game. Aktivitas-aktivitas di atas dilakukan Wibowo ketika pikirannya buntu, atau menurut diksinya sendiri, mandheg.

Tidak seperti Nara yang mendapatkan manfaat besar dari suasana hati atau mood, Wibowo bisa bekerja tanpa mood, walaupun hasilnya tidak maksimal. Menurutnya pengerjaan desain tanpa mood bisa menghabiskan waktu tiga kali lipat dari waktu pengerjaan desain dengan mood. Proses mencari mood pada kasus Wibowo lebih mudah dilakukan, walaupun juga lebih mudah hilang. Wibowo membangun mood dalam setiap tahapan dalam proses kreatifnya dengan beberapa cara seperti mendengarkan musik atau podcast. Sementara itu beberapa hal yang berpotensi merusak mood berkreasinya adalah pekerjaan tambahan yang sifatnya insidental dan di luar agenda harian pribadinya, seperti menerima kunjungan tamu, atau panggilan untuk rapat dan sebagainya.

\section{KESIMPULAN}

Proses kreatif desainer batik memiliki struktur tahapan yang serupa dengan model-model teoretis yang populer, khususnya model teoretis klasik Empat Tahapan Proses Kreatif Graham Wallas. Jika ditilik dari proses berfikir dari awal pekerjaan hingga akhir pekerjaan. Perbedaan karakter dan kepribadian antar desainer tetap menunjukkan indikasi kesamaan tahapan proses kreatif. Pola kerja desainer-desainer BBKB jelas-jelas menunjukkan dukungan terhadap kerangka berfikir Graham Wallas, terutama tentang tahap inkubasi dalam proses kreatif. Teori tentang proses kreatif ini terus berkembang, namun demikian, tahap inkubasi selalu memiliki tempat pada teori-teori proses kreatif modern. 
Pengalaman kerja kedua desainer yang cukup lama membuat keduanya sudah beradaptasi dengan kultur dan pola kerja di perkantoran. Hal tersebut merupakan bentuk peningkatan kompetensi dari seorang pekerja seni yang bekerja di perkantoran. Pekerja seni kantoran ini mampu beradaptasi dengan iregularitas dalam aktivitas penciptaan mereka. Iregularitas tersebut pernah diamati Marion Botella dalam artikelnya tentang beberapa seniman yang tidak bisa bekerja dengan jadwal, atau memaksakan inspirasi, atau bekerja dalam jam kantor (Botella et al., 2013). Peningkatan kompetensi berupa adaptasi tersebut memungkinkan keduanya untuk mengambil sumber daya yang dibutuhkannya untuk berkreasi, dan tetap menghasilkan karya walaupun berada di dalam tatanan jadwal kerja di lingkungan perkantoran.

Adapun kecenderungan karakter pribadi masing-masing desainer (introvert dan extrovert) memberikan kekuatan kepada keduanya dengan cara yang berbeda. Karakter pertama memberikan lebih sedikit ruang untuk terjadinya konflik batin saat pengambilan keputusan dalam konteks perancangan desain. Sedangkan karakter kedua memberikan suplai faktor material dan sosial yang melimpah bagi desainer untuk berkontemplasi. Di sisi lain, kedua karakter juga memiliki kelemahan. Namun demikian tingginya jam terbang dan kompetensi dasar kedua desainer serta masa adaptasi dengan pola kerja di perkantoran membuat kelemahan pribadi tersebut bisa sedikit dikurangi.

\section{SARAN}

Teori Graham Wallas tentang empat tahapan proses kreatif, persiapan (preparation), inkubasi (incubation), illuminasi (ilumination), dan verifikasi (verification) mendapatkan banyak dukungan dan argumentasi mulai dari awal digagaskan hingga saat ini. Sudah banyak penelitian bertajuk proses kreatif pada cabang-cabang kesenian seperti puisi, seni lukis, seni digital dan sebagainya.

Tiap-tiap cabang kesenian tersebut memiliki karakteristik penciptaan yang berbeda-beda terkait dengan teks dan konteksnya. Untuk bisa mengkaji secara keseluruhan dibutuhkan penelitian yang lebih menyeluruh terhadap proses kreatif dalam pembuatan cabang seni lain. Salah satu cabang seni yang belum banyak dikaji dengan mewacanakan kerangka berfikir proses kreatif adalah seni batik, sehingga diperlukan lebih banyak penelitian tentang kreativitas dan proses kreatif di bidang batik.

Untuk kemajuan dunia desain batik, desainer batik memerlukan situasi dan kondisi yang khusus untuk bisa memaksimalkan proses kreatif dalam pembuatan desain batik. Situasi dan kondisi khusus bukan berarti perlakuan istimewa ataupun fasilitas lebih. Sebagai perumpamaan, situasi dan kondisi ruang kerja yang optimal bagi seorang dokter bedah tentunya akan berbeda dengan situasi dan kondisi ruang kerja yang dibutuhkan oleh seorang dokter spesialis anak. Begitu pula profesi desainer dalam ekosistem kerja perkantoran, pengaturanpengaturan situasi dan kondisi tertentu sangat diperlukan untuk mengoptimalkan proses kreatifnya. Untuk itu, peneliti menyarankan adanya penelitian lebih lanjut untuk bisa menentukan situasi dan kondisi seperti apa yang dibutuhkan seorang desainer batik.

\section{DAFTAR PUSTAKA}

Botella, M., Glaveanu, V., Zenasni, F., Storme, M., Myszkowski, N., Wolff, M., \& Lubart, T. (2013). How artists create: Creative process and multivariate factors. Learning and Individual Differences, 26, 161-170. https://doi.org/10.1016/j.lindif.2013.02.008

Botella, M., \& Lubart, T. (2019). From Dynamic Processes to Dynamic Creative Process. In 
R. A. Beghetto \& G. E. Corazza (Eds.), Dynamic Perspectives on Creativity: New Direction for Theory, Research and Practice in Education (4th ed.). Springer. http://www.springer.com/series/13904

Botella, M., Nelson, J., \& Zenasni, F. (2019). It Is Time to Observe the Creative Process: How to Use a Creative Process Report Diary (CRD). Journal of Creative Behavior, 53(2), 211-221. https://doi.org/10.1002/jocb.172

Botella, M., Zenasni, F., \& Lubart, T. (2011). A Dynamic and ecological approach to the artistic creative process of arts students: An empirical contribution. Empirical Studies of the Arts, 29(1), 17-38. https://doi.org/10.2190/EM.29.1.b

Botella, M., Zenasni, F., \& Lubart, T. (2018). What are the stages of the creative process? What visual art students are saying. Frontiers in Psychology, 9(NOV). https://doi.org/10.3389/fpsyg.2018.02266

Bunnin, N., \& Yu, Y. (2004). The Blackwell Dictionary of Western Philosophy (1st ed.). Blackwell Publishing.

Crawford, R., \& Willhoff, A. (2013). Stillness in the Composition Classroom: Insight, Incubation, Improvisation, Flow, and Meditation. The Journal of the Assembly for Expanded Perspectives on Learning, 19(1), 9.

Ernawati, E. (2019). Kajian Estetika Seni Batik Kontemporer Melalui Karya Kolaborasi Seniman Agus Ismoyo-Nia Fliam. Studi Budaya Nusantara, 3(1), 64-84. https://doi.org/10.21776/ub.sbn.2019.003. 01.05

Eskak, E. (2020). Kajian Manfaat Teknologi Informasi dan Komunikasi (TIK) Untuk Meningkatkan Daya Saing Industri Kreatif Kerajinan dan Batik Di Era Industri 4.0. Prosiding Online Seminar Nasional Batik Dan Kerajinan, 2(1), B.10.
Freyd, M. (1924). Introverts and Extroverts. Psychological Review, 31(1), 74-87. https://doi.org/10.1037/h0075875

Lubart, T. (1994). Creativity. In R. J. Sternberg (Ed.), Thinking and Problem Solving (pp. 289-332). Academic Press.

Lubart, T. (2000). Models of the creative process: Past, present and future. Creativity Research Journal, 13(3-4), 295-308. https://doi.org/10.1207/s15326934crj1334_ 07

Lubart, T. (2018). Introduction. In T. Lubart (Ed.), The Creative Process: Perspectives from Multiple Domains (1st ed., pp. 89-122). Palgrave Macmillan. https://doi.org/10.1057/978-1-137-505637

Martindale, C. (1995). Creativity and Connectionism. In Smith, Steven M., T. B. Ward, \& R. A. Finke (Eds.), The Creative Cognition Approach (pp. 249-268). The MIT Press.

Rahayu, D. (2016). Kreativitas Batik Natural Sarwidi Desa Jarum Bayat Klaten. Institut Seni Indonesia Surakarta.

Sadler-Smith, E. (2015). Wallas' Four-Stage Model of the Creative Process: More Than Meets the Eye? Creativity Research Journal, 27(4), 342-352. https://doi.org/10.1080/10400419.2015.10 87277

Wallas, G. (1926). The Art Of Thought. Jonathan Cape.

Wardi. (2017). Penerbitan Majalah Dinamika Kerajinan dan Batik Balai Besar Kerajinan dan

Batik. https://bbkb.kemenperin.go.id/index.php/ page/show/majalah_dkb_0

Wardoyo, S. (2018). Kajian Estetika Motif Batik Girilayu Kabupaten Karanganyar. Corak, $7(2)$,

117-126. https://doi.org/10.24821/corak.v7i2.2676 
IKh Dinamika Kerajinan dan Batik: Majalah Ilmiah. Vol. 38 No. 1, Juni 2021, hal. 79 - 92 